\title{
MICROBIAL PRODUCTION OF L-LYSINE
}

\section{PRODUCTION BY AUXOTROPHS OF BREVIBACTERIUM FLAVUM}

\author{
KONOSUKE SANO AND ISAMU SHIIO \\ Central Research Laboratories, Ajinomoto Co., Inc., Kawasaki, Japan
}

(Received July 11, 1967)

\begin{abstract}
Seven homoserine, 42 methionine, 42 threonine, and 15 isoleucine auxotrophs were obtained from Brevibacterium flavum No. 2247 (ATCC No. 14067) by X-ray irradiation and N-methyl-N'-nitro-N-nitrosoguanidine treatment.

Concerning the L-lysine-producing ability, the homoserine auxotrophs were the best and about one-half of the threonine auxotrophs ranked next. The rest of threonine auxotrophs and all of the methionine and isoleucine auxotrophs produced little of L-lysine.

Investigation on enzyme activities of threonine synthesis revealed that L-lysine-producing threonine auxotrophs lacked homoserine kinase and accumulated the substrate, L-homoserine. On the other hand, the rest which produced little L-lysine and fairly much phosphohomoserine lost the threonine synthase activity.
\end{abstract}

Generally, the production of metabolites by microorganisms is controlled by regulatory mechanisms, feedback inhibition, and repression, which occur in the presence of some metabolite(s), especially of endproduct(s). Consequently, the amount of metabolites in the cell is maintained at a very fixed level. Therefore, in order to overproduce some metabolite(s) using microorganisms, one should release them from these regulatory mechanisms.

One of the cases realized is the production of metabolites such as amino acids and nucleic acids using microbial auxotrophs. The fact that the accumulation of metabolites by them occurs only in a limited concentration of the required substances shows that these auxotrophs are released simultaneously from the two regulatory mechanisms when they have consumed the growth factors, and they begin to overproduce the precursors before the genetic blocks or the related compounds derived from them.

In the case of L-lysine production, some auxotrophs, especially the homoserine (methionine plus threonine) auxotrophs of Micrococcus glutamicus, have been reported as heavy excretors (1). Other mutants, such as the threonine, methionine, and isoleucine auxotrophs, were also reported as producers of L-lysine, but they are inferior to the homoserine auxotrophs (2). 
However, these reports did not deal with sufficient number of mutants to compare the producing ability of L-lysine satisfactorily. Therefore, we isolated more than 100 mutants relating to L-lysine biosynthesis, such as the homoserine, methionine, threonine, and isoleucine auxotrophs, from Brevibacterium flavum No. 2247 (ATCC No. 14067), one of L-glutamateproducing strains, and compared their L-lysine-producing abilities.

As a result, it became clear that the homoserine auxotrophs were the most powerful producers of L-lysine as Micrococcus glutamicus, but other auxotrophs gave fairly different data from that of Micrococcus glutamicus. Namely, the methionine, and isoleucine auxotrophs produced little L-lysine, and the threonine auxotrophs separated into two groups, powerful or weak producers of L-lysine.

\section{MATERIALS AND METHODS}

Bacterial strains. Brevibacterium flavum No. 2247 (ATCC No. 14067) was the parental strain, from which many auxotrophs such as the homoserine, threonine, and methionine auxotrophs were obtained by X-ray irradiation or by treatment with $\mathrm{N}$-methyl-N'-nitro-N-nitrosoguanidine (NG).

Culture media. The following media were employed.

Medium A: $10 \mathrm{~g}$ polypeptone, $10 \mathrm{~g}$ yeast extract, $5 \mathrm{~g} \mathrm{NaCl}$, and 1,000 $\mathrm{ml}$ tap water, adjusted to $\mathrm{pH} 7.2$.

Medium B: $5 \mathrm{~g}$ glucose, $1.5 \mathrm{~g}\left(\mathrm{NH}_{4}\right)_{2} \mathrm{SO}_{4}, 1.5 \mathrm{~g}$ urea, $1 \mathrm{~g} \mathrm{KH}_{2} \mathrm{PO}_{4}, 3 \mathrm{~g}$ $\mathrm{K}_{2} \mathrm{HPO}_{4}, 0.1 \mathrm{~g} \mathrm{MgSO}_{4} \cdot 7 \mathrm{H}_{2} \mathrm{O}, 0.001 \mathrm{~g} \mathrm{CaCl} \cdot 2 \mathrm{H}_{2} \mathrm{O}, 30 \mu \mathrm{g} d$-biotin, $100 \mu \mathrm{g}$ thiamine $\cdot$ $\mathrm{HCl}, 1 \mathrm{ml}$ trace element solution, and $1,000 \mathrm{ml}$ distilled water. The $\mathrm{pH}$ was 7.0 after sterilization. The trace element solution consisted of $8,800 \mathrm{mg}$ $\mathrm{ZnSO}_{4} \cdot 7 \mathrm{H}_{2} \mathrm{O}, 970 \mathrm{mg} \mathrm{FeCl} \cdot 6 \mathrm{H}_{2} \mathrm{O}, 393 \mathrm{mg} \mathrm{CuSO}{ }_{4} \cdot 5 \mathrm{H}_{2} \mathrm{O}, 88 \mathrm{mg} \mathrm{Na} \mathrm{B}_{4} \mathrm{O}_{7} \cdot \mathrm{H}_{2} \mathrm{O}$, and $1,000 \mathrm{ml}$ distilled water.

Medium B-1 was made up of medium B and 1\% growth factor solution to promote the growth of Brevibacterium. The growth factor solution is a supernatant from 48-hr culture broth in which Bacillus megaterium, obtained from the Pasteur Institute, had been grown. The medium used for Bacillus was medium B. The solution contained little amino acids and nucleic acids, but promoted the growth of No. 2247 very much.

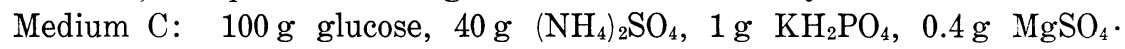
$7 \mathrm{H}_{2} \mathrm{O}, 2 \mathrm{mg} \mathrm{Fe} \mathrm{Fe}^{2+}, 2 \mathrm{mg} \mathrm{Mn} \mathrm{Mn}^{2+}, 300 \mu \mathrm{g} d$-biotin, $200 \mu \mathrm{g}$ thiamine $\cdot \mathrm{HCl}, 2 \mathrm{ml}$ Mieki (amino acids mixture), $600 \mathrm{mg}$ L-threonine, $200 \mathrm{mg}$ L-methionine, $50 \mathrm{~g}$ $\mathrm{CaCO}_{3}$, and $1,000 \mathrm{ml}$ distilled water. The $\mathrm{pH}$ was 7.5 after sterilization.

The concentration of agar, if employed, was $2 \%$.

Isolation of mutants. (A) The wild type strain No. 2247 was grown in medium $\mathrm{A}$ at $30^{\circ}$ with shaking for $18 \mathrm{hr}$. Then $3 \mathrm{ml}$ of the culture, containing $10^{9}-10^{10}$ cells was exposed to X-ray (Matsuda X-ray projector, 168 $\mathrm{kV}, 25 \mathrm{~mA}$ ) at the dosage of 96,000 or $144,000 \mathrm{R}$. The survival fractions were $8.5 \%$ and $0.6 \%$, respectively. Then the irradiated suspension was added 
to 9 volumes of fresh A medium.

(B) An 18-hr cultivated broth described above was added to 39 volumes of medium A and cultivated for $5 \mathrm{hr}$. This exponentially growing cell suspension was added to 39 volumes of medium A containing $250 \mu \mathrm{g} / \mathrm{ml} \mathrm{NG}$ and further incubated aerobically for $30 \mathrm{~min}$. After this treatment, cells were harvested by centrifugation, washed once, and resuspended in an equal volume of medium A.

These treated cell suspensions, (A) and (B), were cultivated for 20-24 hr to stabilize the mutants. After a suitable dilution, cells were plated onto the solid medium A. When colonies appeared, the replica method (3) was applied to isolate the auxotrophic mutants. Then the method of auxanography (4) was applied using L-homoserine, L-methionine, and so on for selection of required auxotrophs.

Cultivation of auxotrophs. To detect the ability for producing L-lysine and the enzyme activity in the mutants isolated, $20 \mathrm{ml}$ each of medium $\mathrm{C}$ was placed in a 500-ml shaker flask and inoculated with a loopful of cells grown on medium A for $48 \mathrm{hr}$. After shaking at $30^{\circ}$ for $23 \mathrm{hr}$, cells were harvested for enzyme source. For the determination of L-lysine accumulated, 72 -hr culture was employed.

Determination of amino acids. L-Lysine and other amino acids accumulated were identified with authentic samples by paper chromatography using the solvent system of dicyclohexylamine, acetone, butanol, and water (2:10:10:5 by volume).

Quantitative determination was made by the following methods. The acidic ninhydrin method of CHINARD (5) was used for the colorimetric determination of L-lysine. Microbial assay method was adopted for DL-alanine, glycine, L-homoserine, L-lysine, L-proline, and L-valine. In order to estimate phosphohomoserine, the enzyme reaction mixture or cell extract was applied to a Dowex-50 $\times 8$ column $\left(\mathrm{H}^{+}\right.$form). Phosphohomoserine was then eluted with distilled water and the eluate was estimated colorimetrically using ninhydrin, essentially the same as described by YEMM AND COCKING (6).

To extract phosphohomoserine, cells grown for $23 \mathrm{hr}$ in medium $\mathrm{C}$ were harvested by centrifugation, washed twice with $0.85 \% \mathrm{NaCl}$, and resuspended in $0.1 \mathrm{~m}$ Tris buffer, $\mathrm{pH} 7.2$, (final concentration, $1 \mathrm{~g}$ wet cells $/ 4.7 \mathrm{ml}$ ). This suspension was boiled for $15 \mathrm{~min}$ to extract intracellular phosphohomoserine. After centrifugation to eliminate the cell debris, $1 \mathrm{ml}$ of the supernatant was applied to the Dowex column for analysis.

Enzyme assay. The method for the preparation of enzyme extract and for the enzyme assay were the same as described in the previous paper (7).

\section{RESULTS}

Isolation of auxotrophs. As a result of X-ray irradiation (two experiments) and NG treatment (four experiments) on Brevibacterium flavum 
No. 2247, 7 homoserine, 42 methionine, 42 threonine, and 15 isoleucine auxotrophs were obtained and employed in further experiments. Table 1 shows the summarized results. Some of the mutants obtained grew so weak that they were omitted from further experiments.

L-Lysine-producing ability. These mutants were cultivated in medium $\mathrm{C}$ at $30^{\circ}$ for $72 \mathrm{hr}$ with shaking and the accumulation of amino acids was checked by paper chromatography, colorimetry and microbioassay.

As indicated in Fig. 1, L-lysine-producing ability of all homoserine auxotrophs was very strong and the average yield was $36 \mathrm{~g} /$ liter (as L-lysine. $\mathrm{HCl}$ ). According to the metabolic map (Fig. 2), methionine auxotrophs include four types of mutants blocked at different steps. Examination by auxanography characterized six as the cystathionine-requiring mutants (responsed to DLcystathionine, DL-homocysteine, and L-methionine), none as homocysteinerequiring mutants (responsed to DL-homocysteine, and L-methionine), and 36 as methionine-requiring mutants (responsed to L-methionine alone). Cystathionine auxotrophs may be divided further using succinylhomoserine. All of the methionine auxotrophs produced little more L-lysine than the wild type. Twelve representative strains are shown in Fig. 1. Average yield was $3 \mathrm{~g} /$ liter. Further, omission of L-threonine from the production medium had no effect on the production of L-lysine.

In addition, all the 15 isoleucine auxotrophs of No. 2247 tested accumulated a small amount of amino acids in the medium $\mathrm{C}$ supplemented with $200 \mathrm{mg} /$ liter of L-isoleucine. Some of the homoserine and threonine auxotrophs produced much L-lysine in the same medium.

In the case of threonine auxotrophs, nearly half of the mutants produced a marked amount of L-lysine (average yield was $17 \mathrm{~g} /$ liter). The producing

Table 1. Isolation of auxotrophs from Brevibacterium flavum No. 2247.

\begin{tabular}{|c|c|c|c|c|c|c|c|c|}
\hline \multirow{2}{*}{$\begin{array}{l}\text { Experimental } \\
\text { number }\end{array}$} & \multirow{2}{*}{ Mutagen $^{a}$} & \multirow{2}{*}{$\begin{array}{l}\text { Parental } \\
\text { strain }\end{array}$} & \multirow{2}{*}{$\begin{array}{l}\text { No. of } \\
\text { colonies } \\
\text { tested }\end{array}$} & \multicolumn{5}{|c|}{ No. of auxotrophs appeared } \\
\hline & & & & $\mathrm{hse}^{-}$ & met- & thr- & ile $^{-}$ & , met- \\
\hline 1 & $\mathrm{X}$-ray & 2247 & 33,400 & 1 & 5 & 8 & - & - \\
\hline 2 & $\mathrm{X}$-ray & 2247 & 19,800 & 2 & 4 & 3 & - & - \\
\hline 3 & NG & 2247 & 15,000 & 5 & 22 & 14 & 16 & - \\
\hline 4 & NG & 2247 & 2,100 & 1 & 3 & 19 & - & - \\
\hline 5 & NG & 2247 & 15,000 & 0 & 11 & 7 & - & - \\
\hline 6 & NG & $\begin{array}{l}\mathrm{T}-36 \\
\left(\operatorname{thr}^{-}\right)\end{array}$ & 9,400 & - & - & - & - & 11 \\
\hline
\end{tabular}

a X-Ray dose in experiment 1 was $144,000 \mathrm{R}$ and in experiment $2,9,600$. NG means N-methyl-N'-nitro-N-nitrosoguanidine. The dose used was $250 \mu \mathrm{g} / \mathrm{ml}$ in medium A for 30 minutes shaking at $30^{\circ}$.

${ }^{b} \mathrm{~T}-36$ was the best producer of L-lysine in the threonine auxotrophs obtained and lacked the homoserine kinase activity. 


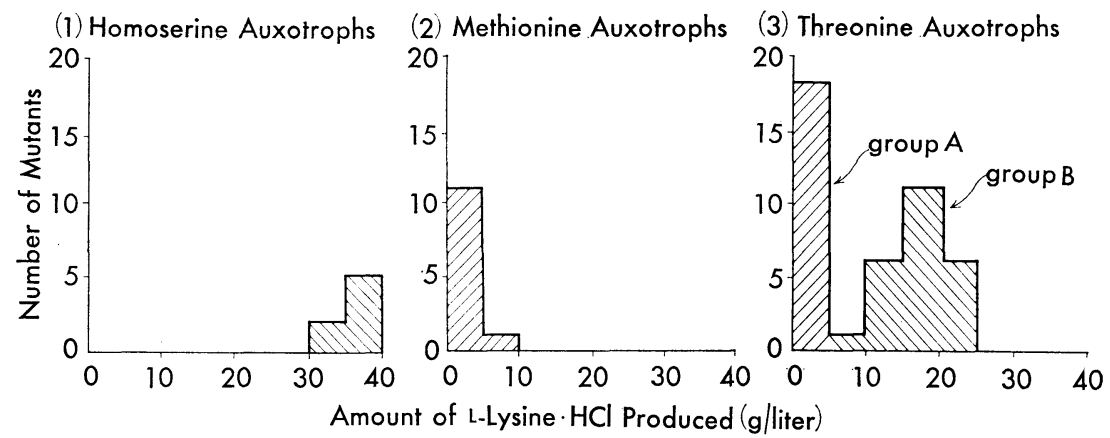

Fig. 1. Deviation pattern of L-lysine-producing ability in various auxotrophs.

Cultivation was carried out at $30^{\circ}$. Seeded $20 \mathrm{ml}$ of medium $\mathrm{C}$ was placed in a $500-\mathrm{ml}$ shaker flask and incubated aerobically. Composition of medium C: $100 \mathrm{~g}$ glucose, $40 \mathrm{~g}\left(\mathrm{NH}_{4}\right)_{2} \mathrm{SO}_{4}, 1 \mathrm{~g} \mathrm{KH}_{2} \mathrm{PO}_{4}, 0.4 \mathrm{~g} \mathrm{MgSO}_{4} \cdot 7 \mathrm{H}_{2} \mathrm{O}, 2 \mathrm{mg} \mathrm{Fe}{ }^{2+}, 2 \mathrm{mg} \mathrm{Mn}{ }^{2+}, 200 \mu \mathrm{g}$ thiamine $\cdot \mathrm{HCl}, 300 \mu \mathrm{g} d$-biotin, $2 \mathrm{ml}$ Mieki (amino acids mixture), $600 \mathrm{mg}$ L-threonine, $200 \mathrm{mg}$ L-methionine, $50 \mathrm{~g} \mathrm{CaCO}_{3}$, and $1,000 \mathrm{ml}$ distilled water. Colorimetric method was used to determine the amount of L-lysine.

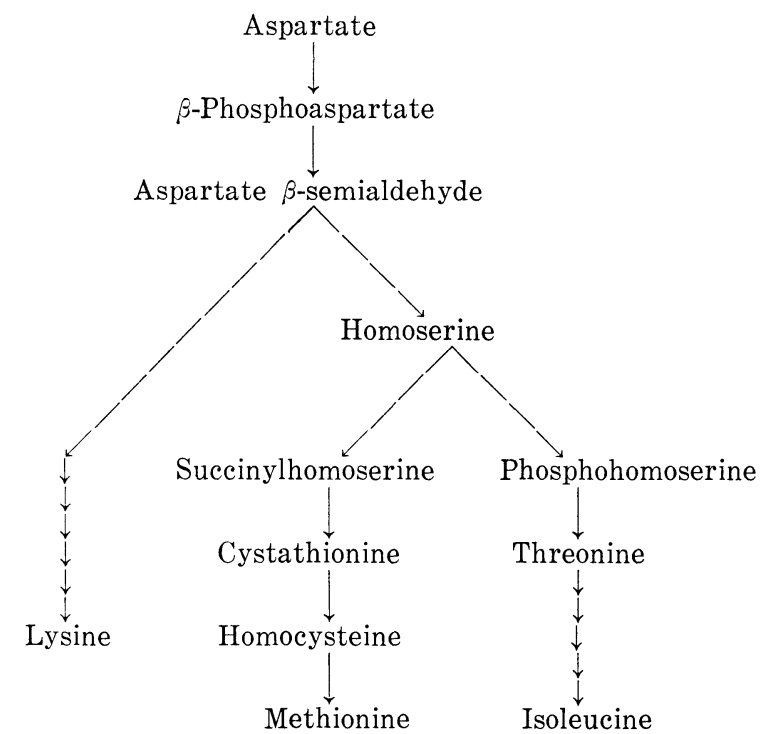

Fig. 2. Biosynthesis of lysine, methionine, threonine, and isoleucine in Escherichia coli.

abilities of the rest of 18 strains were negligible (average yield, $2.5 \mathrm{~g} /$ liter). The former group (group B) also had better ability to produce total amino acids than the latter.

Table 2 indicates typical pattern of amino acids produced by various mutants. 
Table 2. Production of amino acids by various mutants derived from Brevibacterium flavum No. 2247

\begin{tabular}{|c|c|c|c|c|c|c|c|c|}
\hline \multirow[b]{2}{*}{ Character } & \multirow{2}{*}{$\begin{array}{l}\text { No. of } \\
\text { mutants }\end{array}$} & \multirow{2}{*}{$\begin{array}{l}\text { Typical } \\
\text { strain }\end{array}$} & \multicolumn{6}{|c|}{ Amount of products (g/liter) } \\
\hline & & & $\begin{array}{c}\text { L-Lysine } \\
\cdot \mathrm{HCl}\end{array}$ & $\begin{array}{l}\text { L-Homo } \\
\text { serine }\end{array}$ & Glycine & L-Proline & L-Alanine & $\begin{array}{c}\mathrm{L}- \\
\text { Valine }\end{array}$ \\
\hline $\operatorname{thr}^{-}\left(\mathrm{A}_{1}\right)$ & 16 & $\mathrm{~T}-15$ & 1.4 & 0.0 & 0.2 & 0.0 & 0.2 & 0.5 \\
\hline $\operatorname{thr}^{-}\left(\mathrm{A}_{2}\right)$ & 2 & $\mathrm{~T}-28$ & 1.7 & 0.0 & 3.9 & 0.0 & 0.7 & 1.9 \\
\hline thr $^{-}$(B) & 24 & $\mathrm{~T}-36$ & 26.4 & 11.6 & 0.4 & 0.9 & 0.5 & 1.6 \\
\hline $\mathrm{hse}^{-}$ & 7 & H-1013 & 42.6 & 0.0 & 0.4 & 0.0 & 0.0 & 1.6 \\
\hline $\operatorname{thr}^{-}$, met- & 11 & TM-15 & 23.4 & 10.6 & 0.2 & 0.4 & 0.5 & 1.4 \\
\hline met- & 4? & M-78 & 1.6 & 0.0 & 0.5 & 0.0 & 1.0 & 2.1 \\
\hline wild & 1 & 2247 & 0.1 & 0.0 & 0.3 & 0.0 & 0.1 & 2.2 \\
\hline
\end{tabular}

Culture conditions used were similar to that described in Fig. 1. The amounts of the products were determined by microbiological assay.

All of the threonine auxotrophs belonging to group (A), except the two which produced fairly large amounts of glycine, produced neither L-lysine nor other amino acids. Wild-type strain and all of the methionine auxotrophs also produced small amount of amino acids. On the other hand, the members of the group (B) of the threonine auxotrophs accumulated large amounts of Llysine with additional L-homoserine and L-proline. The homoserine auxotrophs were the best L-lysine producers and accumulated none of other amino acids.

Considering the results given in Fig. 1 and Table 2, it is suggested that L-lysine-producing ability of the threonine auxotroph may be related to the genetic block in the biosynthetic pathway.

Determination of genetic block of the threonine auxotrophs. Ten threonine auxotrophs, whose L-lysine-prcducing abilities varied widely, were examined for their enzyme activities concerning the threonine synthesis, homoserine kinase, and threonine synthase.

The results revealed, as expected, that all of the threonine auxotrophs tested lacked either homoserine kinase or threonine synthase. The former belonged to group (B), the latter to group (A) (Table 3).

Accumulation of phosphohomoserine. It might be expected that the threonine auxotrophs lacking the activities of threonine synthase would produce phosphohomoserine, similarly as the threonine auxotrophs lacking the activities of homoserine kinase produced L-homoserine, the substrate of homoserine kinase.

Actually, in the course of enzyme assay, the presence of phosphohomoserine in the cell extract was suspected. The cell extract of a threonine auxotroph lacking the activity of threonine synthase, T-15, obtained by boiling for 15 $\min$ in $0.1 \mathrm{M}$ Tris buffer ( $\mathrm{pH} 7.2)$ was applied to Dowex $-50 \times 8\left(\mathrm{H}^{+}\right.$form) column. By this treatment, the amino acids usually existing in the cell were 
Table 3. Determination of genetic block of threonine auxotrophs

\begin{tabular}{|c|c|c|c|c|c|c|}
\hline \multirow{3}{*}{$\begin{array}{l}\text { Character } \\
\begin{array}{c} \\
\text { wild }\end{array}\end{array}$} & \multirow{3}{*}{$\begin{array}{l}\text { Strain } \\
2247\end{array}$} & \multirow{3}{*}{$\begin{array}{c}\begin{array}{c}\text { Production of } \\
\text { L-lysine } \cdot \mathrm{HCl} \\
(\mathrm{g} / \text { liter })^{a}\end{array} \\
2.1\end{array}$} & \multicolumn{4}{|c|}{ Srecific $^{b}$ and relative ${ }^{c}$ activity } \\
\hline & & & \multicolumn{2}{|c|}{$\begin{array}{l}\text { Homoserine } \\
\text { kinase }\end{array}$} & \multicolumn{2}{|c|}{$\begin{array}{r}\text { Threonine } \\
\text { synthase }\end{array}$} \\
\hline & & & 0.291 & $(100)$ & 0.048 & (100) \\
\hline thr $r^{-}\left(A_{1}\right)$ & $\mathrm{T}-15$ & 2.5 & 0.326 & (112) & -0.005 & $(0)$ \\
\hline thr- ${ }^{-} \quad \prime$ & $\mathrm{T}-24$ & 3.2 & 0.356 & $(122)$ & 0.000 & $(0)$ \\
\hline $\operatorname{thr}^{-}\left(\mathrm{A}_{2}\right)$ & $\mathrm{T}-29$ & 4.1 & 0.381 & $(131)$ & -0.008 & $(0)$ \\
\hline thr $r^{-} \quad "$ & $\mathrm{~T}-28$ & 4.2 & 0.459 & (158) & 0.002 & ( 4$)$ \\
\hline thr $r^{-}(\mathrm{B})$ & $\mathrm{T}-55$ & 10.4 & -0.015 & $(0)$ & 0.056 & (117) \\
\hline thr ${ }^{-} \quad "$ & $\mathrm{~T}-35$ & 11.2 & 0.013 & $(5)$ & 0.050 & (104) \\
\hline thr ${ }^{-}$ & $\mathrm{T}-60$ & 16.7 & 0.002 & $(1)$ & 0.111 & (231) \\
\hline thr- & $\mathrm{T}-52$ & 18.7 & 0.000 & $0)$ & 0.112 & (233) \\
\hline thr ${ }^{-}$ & $\mathrm{T}-45$ & 23.8 & 0.000 & $(0)$ & 0.079 & (165) \\
\hline $\operatorname{thr}^{-} \quad "$ & $T-36$ & 24.4 & -0.005 & $(0)$ & 0.075 & (156) \\
\hline
\end{tabular}

a L-Lysine was determined by colorimetrical method after $72 \mathrm{hr}$ of cultivation at $30^{\circ}$.

${ }^{b}$ Micromoles phosphohomoserine formed or disappeared for $60 \mathrm{~min}$ per $\mathrm{mg}$ protein. Enzyme solution was prepared from cells grown in medium $\mathrm{C}$ for $23 \mathrm{hr}$.

${ }^{c}$ Relative value compared with No. 2247.

completely adsorbed on the resin and removed from the sample, while phosphohomoserine passed through the column, as in the homoserine kinase assay procedure. To make sure, some identifying experiments were performed; first, the ninhydrin-positive substance in the column effluent was identified by paper chromatography with the enzymatic reaction product from Lhomoserine and ATP, which was catalyzed by homoserine kinase obtained from No. 2247. The solvent systems were (a) butanol:acetic acid: water $=4$ : $1: 1$, (b) dicyclohexylamine: butanol:acetone: water $=2: 10: 10: 5$. Both samples run identically. The values of $R F$ were 0.01 and 0.006 , respectively, and no other spot was observed. Furthermore, after the reaction with 1-fluoro-2, 4-dinitrobenzene in ethanol (8), the two yellow products were identified by paper chromatography using the following solvent systems, $(\alpha)$ butanol saturated with $0.1 \% \mathrm{NH}_{4} \mathrm{OH},(\beta)$ toluene: pyridine: ethylene chlorohydrin $=10: 3: 6$, saturated with $0.8 \mathrm{~N} \mathrm{NH} \mathrm{NH}_{4} \mathrm{OH}(\gamma) 1.5 \mathrm{M}$ phosphate buffer $(\mathrm{pH} 6)$. The two ran identically. The values of RF were $0.05,0.00$ and 0.60 , respectively. Finally, the sample was subjected to examination to clarify whether it could be served as a substrate of threonine synthase. As a result of enzyme reaction using the threonine synthase of No. 2247, reasonable amount of L-threonine was formed corresponding to the decreased amount of phosphohomoserine-like substance. Namely, from $0.36 \mathrm{~mm}$ of the phosphohomoserine-like substance, 
and $0.30 \mathrm{~mm}$ of the reaction product of homoserine kinase, decreased, 0.37 and $0.34 \mathrm{mM}$ of L-threonine were formed, respectively. The identification and determination of L-threonine formed were performed microbiologically by using T-15 and Streptococcus faecalis (ATCC No. 8043). Considering the results described above, it may be decided that the ninhydrin-positive substance in the column effluent was phosphohomoserine.

Then, phosphohomoserine contents of several threonine auxotrophs were estimated colorimetrically using L-leucine as a standard substance. As can be seen in Fig. 3, clear separation into two groups occurred; one group had little phosphohomoserine (average content, $1 \mu$ mole/g dry cells), the other much (average content, $80 \mu \mathrm{moles} / \mathrm{g}$ dry cells). This separation reflected the genetic block of the mutants. Namely, the threonine synthase-lacking mutants accumulated phosphohomoserine. In addition, no phosphohomoserine was detected in the cells of the wild-type strain (No. 2247), a homoserine auxotroph

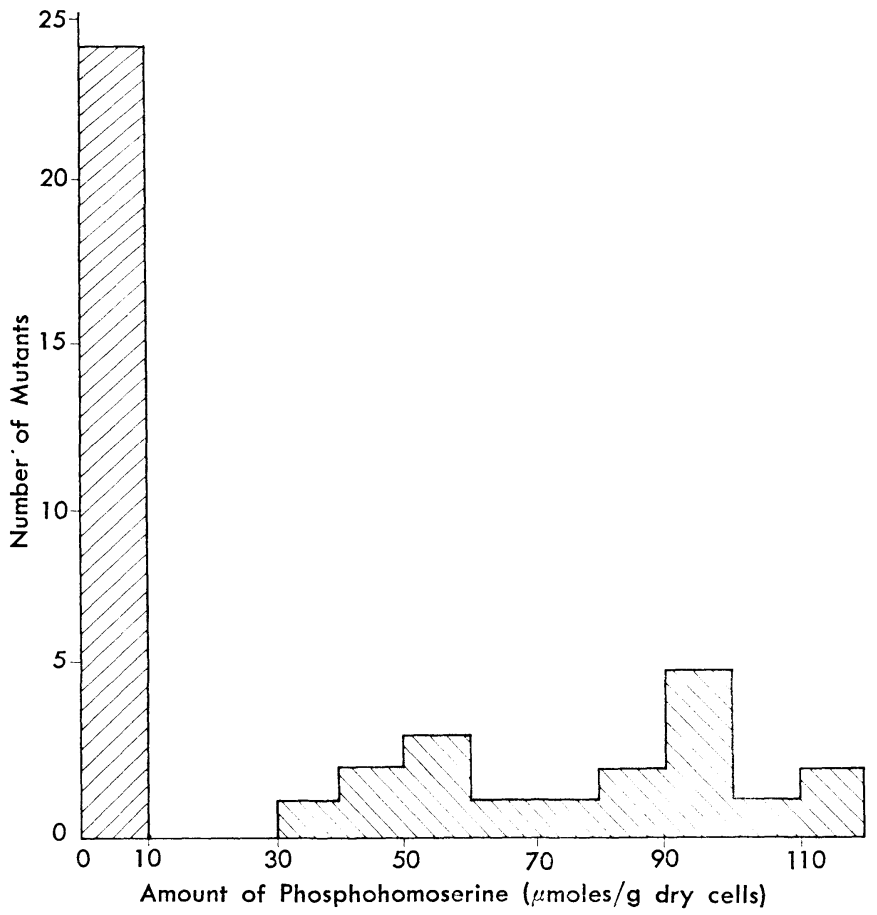

Fig. 3. Deviation pattern of phosphohomosarine-producing ability in the threonine auxotrophs.

Phosphohomoserine was extracted by boiling in $0.1 \mathrm{M}$ Tris buffer ( $\mathrm{pH} 7.2)$ for 15 minutes from the $23-\mathrm{hr}$ cells grown in the medium $\mathrm{C}$. 
(H-1013), and a methionine auxotroph (M-78). There also existed much phosphohomoserine in the culture broth of the threonine auxotrophs lacking the activity of threonine synthase, so the maximum of the total amount was as large as $0.8 \mathrm{~g} /$ liter.

\section{DISCUSSION}

Comparative studies on L-lysine-producing abilities of mutants, such as the homoserine, methionine, threonine, and isoleucine auxotrophs derived from Brevibacterium flavum No. 2247, revealed that the homoserine auxotroph was the best producer of L-lysine and that the threonine auxotroph lacking the activity of homoserine kinase was the next. The latter was accompanied by simultaneous production of L-homoserine and, as its result, the total amount of L-lysine and L-homoserine produced by the two auxotrophs were nearly equal showing that the operation of aspartokinase would be similar in the two auxotrophs.

It has been demonstrated that, in Brevibacterium flavum No. 2247, aspartokinase acting in the first step of L-lysine, L-threonine, and L-methionine biosynthesis received a concerted feedback inhibition by L-threonine plus L-lysine (7). The threonine auxotroph lacking the activity of threonine synthase, however, produced little of L-lysine in spite of the L-threonine exhausting condition. This discrepancy may be ascribed to the possible inhibiting effect caused by phosphohomoserine, which accumulated specifically in this mutant.

Considering the result that both the methionine and isoleucine auxotrophs produced little L-lysine, starvation of methionine or isoleucine from the cell may have no advantage on L-lysine production.

The present result that the homoserine auxotroph is the best producer of L-lysine is similar to the result obtained with Micrococcus glutamicus, although only few auxotrophs were available for the comparison in the latter case. In contrast with results with Brevibacterium flavum, other mutants, the isoleucine, threonine, and methione auxotrophs, in this order, were reported as much producers of L-lysine in Micrococcus glutamicus.

The fact that two kinds of threonine auxotrophs were obtained from Brevibacterium flavum, the one lacking the activity of homoserine kinase and accumulating L-homoserine in the medium, the other lacking the activity of threonine synthase and accumulating phosphohomoserine, suggests the presence of the same threonine biosynthetic pathway in this organism as in Escherichia coli.

The authors are indebted to Director, Mr. S. Motozaki, Dr. T. Yoshida, Dr. N. Katsuya, and Dr. T. Tsunoda of this Company for the helpful encouragement during the course of this work and they also thank Mr. M. Kasai for his technical assistance. 


\section{REFERENCES}

1) S. Kinoshita, K. Nakayama and S. Kitada: J. Gen. Appl. Microbiol., 4, 128 (1958).

2) K. Nakayama, S. Kitada and S. Kinoshita: Symposium on Amino Acid Fermentation (Japan), 2, 105 (1960).

3) J. Lederberg and E. M. LederberG: J. Bacteriol., 63, 399 (1952).

4) G. Pontecorvo: J. Gen. Microbiol., 3, 122 (1949).

5) F. P. Chinard: J. Biol. Chem., 199, 91 (1952).

6) E. W. Yemm and E. C. Cocking: Biochem. J., 58, xii (1954).

7) R. Miyajima, S. Otsuka and I. Shiro: J. Biochem. (Tokyo), in press.

8) W. A. Schroeder and J. LeGette: J. Am. Chem. Soc., 75, 4612 (1953). 